\title{
Regional Disparity and Sustainable Development in North-Eastern States of India: A Policy Perspective
}

\author{
S.N. Singh \\ Dr, Associate Professor of Economics and Law in the Department of Economics, Faculty of Business and \\ Economics, Mettu University, Ethiopia
}

\begin{abstract}
Regional disparity is one of the obstacles for ensuring sustainable development in India particularly north eastern regions. To accelerate the growth amongst regions the Central government as well as state government have launched several special schemes besides the Central Ministries have been mandated to allocate $10 \%$ of their plan funds for the development of the NE Region. Apart from stepping up public investment, both the Central and the State Governments are taking pro-active steps towards creating an enabling environment for private investment in productive sectors. There is no scope for primary data in the present study however, the paper is solely based on analysis of secondary data particularly poverty estimates for North East Regions for 2004-05 \& 2009-10 based on Tendulkar Methodology and the Press note of Planning Commission on Poverty Estimates, 2009-10. The results reveal that there are regional disparities mainly in context to income, poverty, investment and per capita state net domestic products among eight states of NERs. Although the central government has given more attention to develop all the regions of North-east of India yet many efforts need to be focussed to remove the existing regional disparities. Obviously, the average growth rate of State gross domestic product as well as the state net domestic product is comparatively less than the country level over the period of time from 2004-05 to 2010-11 (at constant price 2004-2005) but surprisingly, the growth rate of these two economic indicators (GSDP \& NSDP) of few states like Sikkim $(18.23 \%, 15.34 \%)$ and Mizoram (11.65\%, $12.22 \%)$ are extremely higher than India level $(10.73 \%, 10.49 \%)$ respectively. The significant change has been noticed during the period of time that the territory sector leading ahead followed by primary sector and manufacturing sector in the composition of Gross State Domestic Product of NER states.
\end{abstract}

The paper has attempted to measures the various central government assisted projects and their impacts on development which in turns caused regional disparities. The policy has also been formulated and recommended not only for balanced development but also and attaining sustainable development come across in the regions.

Keywords: regional disparity, public investment, MDONER, balanced development and sustainable development.

JEL Classification: E61, E66, O1, O2, O4, O5.

(C) The Author, 2018. This article is published with open access at Sumy State University.

\section{Introduction}

The Northeast region can be physiographically categorised into the Eastern Himalayas, Northeast Hills (PatkaiNaga Hills and Lushai Hills) and the Brahmaputra and the Barak Valley Plains. Northeast India (at the confluence of Indo-Malayan, Indo-Chinese, and Indian bio geographical realms) has a predom-inantly humid subtropical climate with hot, humid summers, severe monsoons and mild winters. Along with the west coast of India, this region has some of the Indian sub-continent's last remaining rain forests which support diverse flora and fauna and several crop species. Similarly, reserves of pe-troleum and natural gas in the region constitute a fifth of India's total potential (C Joshua Thomas \& Gurudas Das et al., 2002). The region is covered by the mighty Brahmaputra-Barak river systems and their tributaries. Geographically, apart from the Brahmaputra, Barak and Imphal valleys and some flat lands in between the hills of Meghalaya and Tripura, the remaining two-thirds of the area is hilly ter-rain interspersed with valleys and plains; the altitude varies from almost sealevel to over 7,000 metres $(23,000 \mathrm{ft})$ above MSL. The region's high rainfall averaging around 10,000 millimetres (390 in) and above creates problems of eco-system, high seismic activity and floods. The states of Arunachal Pra-desh and Sikkim have a montage climate with cold, snowy winters and mild summers.

The economy of the regions is agrarian. Little land is available for settled agriculture. Along with settled agriculture, jhum (shifting cultivation) is still practised by a few indigenous groups of people (N.Srivastav et.al., 2000). The inaccessible terrain and internal disturbances has made rapid industrialisation difficult in the region. In the $21^{\text {st }}$ century, there has been recognition among policy makers and economists of the region that the main 
stumbling block for economic development of the North-eastern region is the disadvantageous geographical location. It was argued that globalisation propagates deteroitorialisation and a borderless world which is often associated with economic integration. With 98 percent of its borders with China, Myanmar, Bhutan, Bangladesh and Nepal, Northeast India appears to have a better scope for development in the era of globalisation (Gurudas Das et al., 2004). As a result, a new policy developed among intellectuals and politicians that one direction the North-eastern region must be looking to as a new way of development lies with political integration with the rest of India and economic integration with the rest of Asia, with East and Southeast Asia in particular, as the policy of economic integration with the rest of India did not yield much dividends (D. R. Syiemlieh et al., 2006). With the development of this new policy the Government of India directed its Look East policy towards developing the North-eastern region.

For accelerating rapid growth and socio-economic development in the region the government of India has established the Ministry of Development of North Eastern Region (MDONER) in September 2001, which functions as the nodal Department of the Central Government to deal with matters related to the socio-economic development of the eight States of Northeast India viz., Arunachal Pradesh, Assam, Manipur, Meghalaya, Mizoram, Nagaland, Tripura and Sikkim. MDONER acts as a facilitator between the Central Ministries / Departments and the State Governments of the North Eastern Region including Sikkim in the economic development including removal of infrastructural bottlenecks, pro-vision of basic minimum services, creating an environment for private investment and to remove im-pediments to lasting peace and security in the North Eastern Region including, Sikkim. The Main activ-ities/functions of the DoNER are Non Lapsable Central Pool of Resources (NLCPR), North Eastern Council (NEC), Coordination with the Central Ministries and the State Govts of the NE states, Capacity Building, Advocacy and Publicity, International Cooperation and Enterprises of the Department (Indad hussain, et al., 2005). The ministry has organisations like North Eastern Council (NEC), North Eastern Development Finance Corporation Ltd.(NEDFi), North Eastern Regional Agricultural Marketing Cor-poration Limited (NERAMAC), The Sikkim Mining Corporation Limited. (SMC), North Eastern Hand-looms and Handicrafts Development Corporation (NEHHDC).During the Eight Plan Period and onwards the special attention has been given to the economic development of the region (J.P. Singh et al., 1998). Consecutively, in October 1996, the Central Government's announcement of 'New Initiatives for the North Eastern Region' included a number of measures for the development of the NER which covered poli-cy changes, special area development and development projects in key sectors (C. Khonglah et al., 2008). In order to mobilize financial resources, a policy decision was taken to earmark at least $10 \%$ of the Plan Budget(s) of the Central ministries/departments for development of the North Eastern states.

\section{Research methodology}

The study is based on secondary data particularly poverty estimates for NER for 2004-05 \& 2009-10 based on Tendulkar Methodology and the Press note of Planning Commission on Poverty Estimates, 2009-10. Accordingly, the Tendulkar Committee computed implicit price indices from the 66th Round, NSS (2009-10) data on Household Consumer Expenditure Survey for estimating state wise poverty lines for the year 2004-05. Using these poverty lines and distribution of monthly per capita consumption expenditure based on mixed reference period (MRP), the Tendulkar Committee estimated poverty ratios for the year 2004-05. State Domestic Product is a measure in monetary terms of the volume of all goods and services produced by an economy during a given period of time accounted without duplication. SDP is a reflection of economic development of the State and its determinate Per Capita Income is a suitable measure of the well-being of its people. The estimates of State Domestic Product (SDP) of the Northern states are prepared at current and constant prices by the Directorate of Economics \& Statistics, New Delhi. The estimates of State Domestic Product at current prices are obtained by evaluating the product at current prices prevailing during the year. The estimates of State Domestic Product at current prices, over the time do not reveal actual economic growth because these contain the combined effect of (1) the changes in volume of goods and services and (2) the changes in the prices of goods and services. In order to eliminate the effect of price changes/inflation, the estimates of State Domestic Product are also prepared by evaluating the goods and services at the prices prevailing in the fixed as base year (2004-05) and are known as the estimates of State Domestic Product at constant prices.

Three major components influencing the present revision exercise include (1) revision to the base year to a more recent year (for meaningful analysis of the structural changes in the economy), (2) complete review of the existing data base and methodology employed in the estimation of various macro-economic aggregates including choice of the alternative databases on individual subjects and (3) to the extent feasible, implementing 
the recommendations of the System of National Accounts (1993 and 2008) prepared under the auspices of the Inter Secretariat Working Group on National Accounts comprising of the European Communities (EUROSTAT), International Monetary Fund (IMF), Organization for Economic Cooperation and Development (OECD), United Nations and World Bank. In the new series, efforts have been made to make use of as much current data as possible. Further, the results of latest available surveys have also been made use of. Some of the important sources of data, which have been used in the new series, are as follows:

1. NSS 61st round (2004-05) on employment \& unemployment and consumer expenditure;

2. NSS 62nd round (2005-06) on unorganized manufacturing;

3. NSS 63rd round (2006-07) on services sector;

4. All India Livestock Census, 2003;

5. NSS 59th round (2002-03) on All India Debt and Investment Survey;

6. Population Census, 2001; and

7. Fourth All India Census of Micro, Small and Medium Enterprises, 2006-07.

Further, the results of various studies undertaken by the CSO through the Ministry of Agriculture, Ministry of Environment and Forestry and also CSO's input output transaction tables and the Ministry of Agriculture's Cost of Cultivation Studies have been used in the new series for updating the rates and ratios used to estimate the production/consumption of fodder, market charges paid by the farmer, yield rates of meat, meat products and meat by products for different categories of animals, input rates for agriculture and forestry and the trade and transport margins. The improvements in terms of coverage have been mainly the inclusion of production of industrial wood from trees outside forests (TOF), fodder from forest sources and output of wind power generation in the GSDP estimates. Under the present series estimates of State Domestic Product of Delhi are compiled with effect from 2004-05 to 2009-10. Provisional estimates for 2010-11 have been prepared on the basis of provisional data from CSO and other data providers. Quick estimates and advanced. Estimates of SDP for the year 2011-12 and 2012-13, respectively, have been projected by using extrapolation techniques/national trends at sub-economic activity level of various sub-sectors.

\section{Estimation of SDP}

For the purpose of estimation of SDP, the whole economy of the state has been divided into seventeen (17) sub-sectors in conformity with the procedure followed at the national level to estimate the National Income estimates. The procedure is followed by each state and union territory of the country to make the estimates comparable. The fourteen sectors have been further categorized into three broad sectors as follows.

1. Primary Sectors like Agriculture and Livestock; Forestry and logging; Fishing and Mining and Quarrying.

2. Secondary Sectors like Manufacturing (registered and unregistered both); Electricity; Gas; Water Supply and Construction.

3. Tertiary Sectors like Trade; Hotels and Restaurants; Railways; Transport by Other Means Storage; Communication; Banking and Insurance; Real Estate; Ownership of dwellings; business and legal services and Public Administration and other services. Estimates of these sectors are prepared individually by adopting one or more of the following approaches.

i. Production Approach: In this method, the sum of economic value of all goods and services produced within the State during the year is considered after deducting the inputs consumed in the process of production. This approach is followed in Agriculture, Livestock, Forestry, Fishing, Mining and Quarrying and Manufacturing (Registered) sectors.

ii. Income Approach: The income accrued to the factors of production namely land, labour, capital and entrepreneurship in form of rent, salaries and wages, interest and profit is taken into consideration in estimation of value added. This approach is being followed in Manufacturing (un-registered), Electricity, Gas and water supply, Trade, Hotels and restaurants, Transport, Storage and Communication, Financing, Insurance, Real Estate, Business services, Public Administration and other services.

iii. Expenditure Approach: This method is based on the measurement of income at the stage of disposal. All that is produced is either ultimately consumed or part of it is saved for further consumption or future production of goods and services. Thus, the money value of consumption expenditure plus the savings gives the income. This approach is used in estimating income from construction sector.

**(Population as on $1^{\text {st }}$ March, 2010 has been used for estimating no. of persons below poverty line interpolated between 2001 and 2011 population Census). 


\section{Results and Discussion:}

\section{(i) Gross State Domestic Product}

Gross state domestic product at factor cost assuming constant prices (2004-05) has been calculated for all states in view of comparative analysis. The highest annual average growth rate (Table1.1) was recorded in the state of Sikkim $(18.23 \%)$ followed by Mizoram (11.65 \%), Meghalaya (10.61\%) and Arunachal Pradesh by $10.55 \%$ respectively. However, the total share of NER to India has been declined from 2.95 to $2.64 \%$. Moreover, the declining trends were observed in the state of Assam, Manipur, Nagaland and Tripura, exceptionally the Sikkim has stood with increasing trend and other rest of the states like Arunachal Pradesh and Meghalaya remain stable in the share of growth rate in compare with the country over the period of time from 2004-05 to 2010-11.

\section{(ii) Net State Domestic Product}

Net State Domestic Product is indicated in Annexure (table 1.3) that lays emphasis that there is annual average growth rate of Domestic Product was increased by $10.49 \%$ in 2010-11 over 2004-05 at the India level. However, Total North Eastern Regions registered for $7.70 \%$ over the same period of time. Among NE regions, the highest NSDP growth was recorded in Sikkim (15.34\%) followed by Mizoram (12.22\%), Tripura (10.65\%) and Arunachal Pradesh (10.09). During the same period of time the lowest growth rate was encountered with Assam (6.33\%) and Manipur (6.71\%).

\section{(iii) Per Capita Net State Domestic Product}

Per capita Net State Domestic Product is depends on population of the particular state. At the level of India, the per capita Net State Domestic of North States at constant price of 2004-05 recorded by $8.18 \%$ but in the North East Regions it was only $7.65 \%$ at the same constant period of time. The highest per capita NSDP was in Sikkim (13.08\%) and lowest was reported to Assam only 4.59\%.

\section{(iv) Composition of GSDP of North Eastern States}

The composition of GSDP of North Eastern States is characterised by dominance of Primary \& Tertiary sectors while Secondary sector specially manufacturing remains subdued. Primary sector has contracted but is still higher than national percentages. The tertiary sector is growing due to expansion of public administration, confirming the fact that outside agriculture, Government is the main employer.

\section{Industrial Growth Rate}

The annual average growth rate of industries at the all India level during the period 2004-05 to 2009-10 was $10.42 \%$, however unfortunately it is accounted only $3.94 \%$ in NER. It indicates that the investment in industries is comparatively low as compared to the level of the country.

\section{(vi) Poverty Ratios}

Highest poverty ratio in rural area lies in the state of Tripura even more than the average of all India and followed by Manipur, Assam, Arunachal Pradesh and Sikkim. The scenario of urban area is different from rural areas as the Manipur has highest percentage of poverty ratio even more than the average of the country. In combined of both rural and urban the Tripura has highest poverty ratio as compared to other states in the North East region. The states like Tripura, Manipur, Assam, Arunachal Pradesh and Sikkim are comparatively poor states as the poverty ratio in these states are literally high as compared to other states of North Eastern region. At the all India level rural poverty has declined from 8.0 percentage points from $41.8 \%$ (42\%) in 200405 to $33.8 \%$ in $2009-10$. The urban poverty declined by 4.8 percentage points from $25.7 \%$ to $20.9 \%$.

Poverty has increased in Assam, Manipur, Meghalaya, Mizoram and Nagaland in 2009-10. In case of Meghalaya while combined poverty ratio has increased from $16.1 \%$ in $2004-05$ to $17.1 \%$ in $2009-10$, there is a slight reduction in urban poverty from $24.7 \%$ to $24.1 \%$ in the same period.

\section{Policy recommendations}

Development in phased manner required rational planning that stimulates balanced sustainable development. In development stipulate lying in the sisters states of North East must be based on various strata of direct and indirect investment including Foreign Direct Investment (FDI). However, the following recommendations are suggested for removing regional disparity and ensuring equitable sustainable development in the regions: 
$>$ New horizon of poverty index must be defined based on phased manner of household poverty index and Gross State domestic products.

$>$ Planning of investment must be based on the size of population and the standard of living of the mass connotation with land holding capacity and educational attainment of the family in every region of North East and the priority of Investment must be given to poor regions in all spheres.

$>$ The low index level of regions the labour intensive production system must be enunciated to provide more employment opportunities in order to increase the income of rural unskilled population.

$>$ The results reveals that even the basic elements are very poor in some of the regions and the government must have to focus on elementary primary education, health, infrastructures like rural road, rural electricity etc. Including small scale cottage industries.

$>$ In the new phase of sustainable development the natural resources must be harnessed with advanced technology at only optimum level without disordering ecological balance in the NERs.

$>$ With the changing pattern of life style of people in both urban and rural areas the attainment of professional educational are prerequisite to cope up with the unemployment of qualified skilled persons the central government must have to take initiative based on priorities.

$>$ Skilled based modern infrastructures required to develop the region within short span of time and the government should ensure to provide equal opportunity to all specially women and youth.

\section{Conclusion}

From the viewpoint of sustainable development needs, it is necessary to ensure the development of regions with parity on the one hand and, on the other hand, to reduce the disparity and to ensure the environment protection. The artistic creation is the high degree of proficiency. The complex problems of the human/nature relation are based on certain philosophical foundations in each historical era. The present period can be characterized as the era in which the humans incessantly start turning the higher merry-go-round of substances and energies in order to satisfy their needs, with reality that the bulk of these substances are growing much faster than the human needs.

On one side it displays deficiencies of resources and energy (resource stocks have been stretched) and on the other side it wastes with resources and with energy. Sustainability considers the nature and human from the viewpoint of optimum development of the whole biosphere. The ecological behaviour should not be reduced to the riotous discussions around the nuclear power plants and water structures or industrial complexes. The government must have to focus on these critical issue and make appropriate plan big structures. At the same time, we must consider the impacts of these constructions on the environment and human health.

\section{References}

1. Syiemlieh, D. R., Dutta, A. \& Baruah, S. (2006). Challenges of Development in North East India. Regency Publications.

2. Thomas, Joshua, C. \& Das, Gurudas (ed.). (2002). Dimensions of Development in Nagaland. Regency Publications, New Delhi.

3. Thomas, C. J. (2006). Engagement \& Development: India's North East and Neighbouring Countries. Akansha Publishing House.

4. Das, Gurudas and Thomas, C. J. (2008). Indo-Bangladesh Border Trade-Benefiting from Neighbourhood. Akansha Publishing House.

5. Das, Gurudas and Thomas, C. Joshua (2010). India-China: Trade \& Strategy for Frontier Development. Bookwell.

6. Gopalakrishnan, R. (2001). Research Priorities in North East India With Special Reference to Assam. Regency Publications, New Delhi.

7. Ganguly, J. B. (1996). Sustainable Development in North Eastern Region of India. Regency Publications, New Delhi.

8. Srivastav, N. (2000). Survey of Research in Economics on North East India (1970-1990). Regency Publications, New Delhi.

9. Das, Gurudas (2004). Structural Change Resource and Industry Linkages in North East India. Akansha Publications.

10. Hussain, Imdad (2005). The Guwahati Declaration and the Road to Peace in Assam. Akansha Publications.

11. Singh, J. P., Gopalakrishnan, R., Gassah, L. S., Syiemlieh, D. R. and Thomas, C. J. (1998). Trends in Social Sciences \& Humanities in North East India (1947-98). Regency Publications, New Delhi. 
12. Khonglah, C. (2008). Women in North East India - An Annotated Bibliography. Akansha Publishing House.

\section{Appendices}

Table 1. Gross State Domestic Product at Factor Cost (Constant Prices) (2004-05) North East States from 2004-05 to 2010-11 (Rs. In Crores)

\begin{tabular}{|l|c|c|c|}
\hline \multicolumn{1}{|c|}{ State } & $2004-05$ & $2010-11$ & $\begin{array}{c}\text { (Annual Average Growth } \\
\text { Rate })(\%)\end{array}$ \\
\hline Arunachal Pradesh & 3484 & 5691 & 10.55 \\
\hline Assam & 53398 & 74215 & 6.49 \\
\hline Manipur & 5133 & 7184 & 10.66 \\
\hline Meghalaya & 6559 & 10736 & 11.65 \\
\hline Mizoram & 2682 & 4557 & 7.85 \\
\hline Nagaland & 5839 & 8591 & 18.23 \\
\hline Sikkim & 1739 & 3642 & 9.91 \\
\hline Tripura & 8904 & 14203 & 7.80 \\
\hline Total NER & 87738 & 128819 & 10.73 \\
\hline All India & 2971464 & 4885954 & \\
\hline
\end{tabular}

Source: Central Statistical Organisation (CSO, India).

Table 2. Composition of GSDP of NE States (Percentage)

\begin{tabular}{|l|c|c|c|c|}
\hline \multicolumn{1}{|c|}{ Sector } & $1993-94$ & $1999-00$ & $2004-05$ & $2009-10$ \\
\hline Primary sector & 42.67 & 36.76 & 32.37 & $\begin{array}{c}28.48 \\
(16.93)\end{array}$ \\
\hline Secondary sector & 15.09 & 13.98 & 20.24 & $\begin{array}{c}18.14 \\
(25.76)\end{array}$ \\
\hline Of which manufacturing & 7.24 & 5.99 & 7.59 & $\begin{array}{c}5.79 \\
(15.2)\end{array}$ \\
\hline Tertiary sector & 42.25 & 49.27 & 47.39 & $\begin{array}{c}53.38 \\
(57.29)\end{array}$ \\
\hline $\begin{array}{l}\text { GSDP at factor cost (con- } \\
\text { stant prices) }\end{array}$ & 100.00 & 100.00 & 100.00 & 100.00 \\
\hline
\end{tabular}

Source: CSO India.

Note: Figures in parenthesis show all India percentages.

Table 3. Net State Domestic Product at constant prices (2004-05) North East States (Rs. In Crores)

\begin{tabular}{|l|c|c|c|}
\hline \multicolumn{1}{|c|}{ State } & $2004-05$ & $2010-11$ & $\begin{array}{c}\text { 2004-05 to 2010-11 } \\
\text { Annual Average Growth } \\
\text { Rate) (\%) }\end{array}$ \\
\hline Arunachal Pradesh & 3188 & 5119 & 10.09 \\
\hline Assam & 47181 & 65102 & 6.33 \\
\hline Manipur & 4603 & 6458 & 6.71 \\
\hline Meghalaya & 5846 & 9375 & 10.06 \\
\hline Mizoram & 2400 & 4160 & 12.22 \\
\hline Nagaland & 5421 & 8040 & 8.05 \\
\hline Sikkim & 1511 & 2902 & 15.34 \\
\hline Tripura & 8170 & 13394 & 10.65 \\
\hline Total NER & 78320 & 114550 & 7.70 \\
\hline All India & 2651573 & 4321491 & 10.49 \\
\hline
\end{tabular}

Source: Central Statistical Organisation (CSO). 
Table 4. Per Capita Net State Domestic Product of North East States at constant prices (2004-05) (In Rupees)

\begin{tabular}{|l|c|c|c|}
\hline Arunachal Pradesh & 26610 & 37417 & 6.77 \\
\hline Assam & 16782 & 21406 & 4.59 \\
\hline Manipur & 18640 & 23298 & 4.16 \\
\hline Meghalaya & 24086 & 35932 & 8.19 \\
\hline Mizoram & 24662 & 36732 & 5.16 \\
\hline Nagaland & 30441 & 40957 & 13.08 \\
\hline Sikkim & 26693 & 47655 & 8.76 \\
\hline Tripura & 24394 & 37216 & 7.65 \\
\hline NER & 192308 & 280613 & 8.18 \\
\hline $\begin{array}{l}\text { All India Per Capita Net Na- } \\
\text { tional Income (NNI) }\end{array}$ & 24143 & 35993 & \\
\hline
\end{tabular}

Source: Central Statistical Organisation (CSO, India).

Table 5. Industrial Growth Rate of North East States (In Rs. Crores)

\begin{tabular}{|l|c|c|c|}
\hline \multicolumn{1}{|c|}{ State } & $2004-05$ & $2009-10$ & $\begin{array}{c}2004-05 \text { to 2009-10 } \\
\text { Annual Average Growth } \\
\text { Rate) }(\%)\end{array}$ \\
\hline Arunachal Pradesh & 1112.18 & 1675.29 & 10.13 \\
\hline Assam & 14705.09 & 15104.95 & 0.54 \\
\hline Manipur & 188204 & 2277.49 & 4.20 \\
\hline Meghalaya & 1714.67 & 2617.61 & 10.53 \\
\hline Mizoram & 445.29 & 851.35 & 18.24 \\
\hline Nagaland & 752.30 & $1150.58 *$ & 31.39 \\
\hline Sikkim & 501.54 & 1288.74 & 6.77 \\
\hline Tripura & 2158.84 & 2889.19 & 3.94 \\
\hline Total NER & 23271.95 & 27855.20 & 10.42 \\
\hline Total (Industry All India) & 829783 & 1261999 & \\
\hline
\end{tabular}

Source: Central Statistical Organisation, M/o Statistics \& Progamme Implementation.

Note: Figures pertaining to industrial growth rates for North Eastern States are calculated from CSO data on Gross State Domestic Product at factor cost by industry of origin at constant (2004-05) prices - (State series). Figures pertaining to India's industrial growth rates are calculated from CSO data on GDP by economic activity at constant (2004-05) prices at factor cost. Industry includes mining \& quarrying, manufacturing, electricity, gas \& water supply and construction* For the period 2008-09.

Table 6. Poverty Ratios of North East States - 2004-05 (Tendulkar Methodology)

\begin{tabular}{|c|l|c|c|c|c|c|c|}
\hline & & \multicolumn{2}{|c|}{ Rural } & \multicolumn{2}{c|}{ Urban } & \multicolumn{2}{c|}{ Combined / Total } \\
\hline S1 No. & \multicolumn{1}{|c|}{ States/U.Ts } & $\begin{array}{c}\text { \% age of } \\
\text { persons }\end{array}$ & $\begin{array}{c}\text { No. of Per- } \\
\text { sons (Lakhs) }\end{array}$ & $\begin{array}{c}\text { \%age of per- } \\
\text { sons }\end{array}$ & $\begin{array}{c}\text { No. of Per- } \\
\text { sons (Lakhs) }\end{array}$ & $\begin{array}{c}\text { \% age of per- } \\
\text { sons }\end{array}$ & $\begin{array}{c}\text { No. of Per- } \\
\text { sons (Lakhs) }\end{array}$ \\
\hline 1. & Arunachal Pradesh & 33.6 & 3.2 & 23.5 & 0.6 & 31.4 & 3.8 \\
\hline 2. & Assam & 36.4 & 89.4 & 21.8 & 8.3 & 34.4 & 97.7 \\
\hline 3. & Manipur & 39.3 & 6.7 & 34.5 & 2.3 & 37.9 & 9 \\
\hline 4. & Meghalaya & 14 & 2.9 & 24.7 & 1.2 & 16.1 & 4.1 \\
\hline 5. & Mizoram & 23 & 1.1 & 7.9 & 0.4 & 15.4 & 1.5 \\
\hline 6. & Nagaland & 10 & 1.5 & 4.3 & 0.2 & 8.8 & 1.7 \\
\hline 7. & Sikkim & 31.8 & 1.5 & 25.9 & 0.2 & 30.9 & 1.7 \\
\hline 8. & Tripura & 44.5 & 11.9 & 22.5 & 1.5 & 40 & 13.4 \\
\hline 9. & All India & 42 & 3258.1 & 25.5 & 814.1 & 37.2 & 4072.2 \\
\hline
\end{tabular}

Note: Population as on 1st March 2005 has been used for estimating number of persons below poverty line. (Revised on the basis of 2011 population census). 
Table 7. Poverty ratios of North East States - 2009-10 (Tendulkar Methodology)

\begin{tabular}{|c|l|c|c|c|c|c|c|}
\hline & & \multicolumn{2}{|c|}{ Rural } & \multicolumn{2}{c|}{ Urban } & \multicolumn{2}{c|}{ Combined / Total } \\
\hline S1 No. & States/U.Ts & $\begin{array}{c}\text { \% age of } \\
\text { persons }\end{array}$ & $\begin{array}{c}\text { No. of Per- } \\
\text { sons (Lakhs) }\end{array}$ & $\begin{array}{c}\text { \%age of per- } \\
\text { sons }\end{array}$ & $\begin{array}{c}\text { No. of Per- } \\
\text { sons (Lakhs) }\end{array}$ & $\begin{array}{c}\text { \% age of } \\
\text { persons }\end{array}$ & $\begin{array}{c}\text { No. of Per- } \\
\text { sons (Lakhs) }\end{array}$ \\
\hline 1. & Arunachal Pradesh & 26.2 & 2.7 & 24.9 & 0.8 & 25.9 & 3.5 \\
\hline 2. & Assam & 39.9 & 105.3 & 26.1 & 11.2 & 37.9 & 116.4 \\
\hline 3. & Manipur & 47.4 & 8.8 & 46.4 & 3.7 & 47.1 & 12.5 \\
\hline 4. & Meghalaya & 15.3 & 3.5 & 24.1 & 1.4 & 17.1 & 4.9 \\
\hline 5. & Mizoram & 31.1 & 1.6 & 11.5 & 0.6 & 21.1 & 2.3 \\
\hline 6. & Nagaland & 19.3 & 2.8 & 25.0 & 1.4 & 20.9 & 4.1 \\
\hline 7. & Sikkim & 15.5 & 0.7 & 5.0 & 0.1 & 13.1 & 0.8 \\
\hline 8. & Tripura & 19.8 & 5.4 & 10.0 & 0.9 & 17.4 & 6.3 \\
\hline & All India & 33.8 & 2782.1 & 20.9 & 764.7 & 29.8 & 3546.8 \\
\hline
\end{tabular}

